УДК 378.14+ 378.046.4

ОКСАНА САГАЧ, кандидат історичних наук, доиент кафедри педагогіки та психології Чернігівського обласного інституту післядипломної педагогічної освіти імені К. Д. Ушинського, Україна ORCID.ORG/0000-0002-4504-3405

Oksmos78@ukr.net

\title{
ТЕОРЕТИЧНИЙ АНАЛІЗ ПОНЯТТЯ ПЕДАГОГІЧНІ УМОВИ У КОНТЕКСТІ ПРОФЕСІЙНОГО ЗРОСТАННЯ ВЧИТЕЛІВ
}

\author{
OKSANA SAHACH, PhD in History Assistant Professor \\ of Psychology and pedagogy department, \\ Chernihiv Regional Institute of Postgraduate \\ Pedagogical Education of K. D. Ushynskyi, Ukraine
}

\section{THEORETICAL ANALYSIS OF THE CONCEPT OF PEDAGOGICAL CONDITIONS DUE TO TEACHERS' PROFESSIONAL GROWTH}

\begin{abstract}
У поданому матеріалі представлено аналіз дефініцій умова, педагогічні умови, організаційно-педагогічні умови. Визначено організаційно-педагогічні умови, за яких відбувається процес неперервного професійного зростання вчителя, і виділено його етапи, які, будучи поєднані його цілісністю, відрізняються метою, змістом і методами. Доведено, що професійне зростання педагога $\epsilon$ процесом якісних i кількісних перетворень його професійного потенціалу, що обумовлені як внутрішніми, так і зовнішніми умовами. Умови ж розглянуто як елементи системи, на яких базується педагогічний процес та які забезпечують досягнення конкретної мети.
\end{abstract}

Ключові слова: умови, педагогічні умови, організаційно-педагогічні умови, неперервне професійне зростання.

Summary. It is presented in the article an analysis of the definitions condition, pedagogical conditions, organizational and pedagogical conditions. It is determined organizational and pedagogical conditions in the process of which occurs continuous professional growth of the teacher. Its stages

(C) О. Сагач were underlined with its integrity, are distinguished by purpose, content, and methods. It is proved that professional growth of the teachers is a process of qualitative and quantitative transformations of their professional prospects, which have a result both by internal and external conditions and by managed and unmanaged factors as influencing the specified requirements.

Key words: conditions, pedagogical conditions, organizational and pedagogical conditions, continuous professional growth.

Мета: здійснити теоретичний аналіз педагогічних умов у контексті процесу неперервного професійного зростання вчителів у закладах вищої та неперервної педагогічної освіти.

Постановка проблеми в загальному вигляді. Життя і діяльність людей відбуваються в умовах систематичних та епізодичних, випадкових та предметних, цілеспрямованих та нецілеспрямованих ситуацій, обставин, дій, які спільно або відокремлено впливають на їх розвиток, у тому числі і професійне зростання. Ефективність професійного зростання вчителів у системі неперервної педагогічної освіти визначається відповідним комп- лексом педагогічних та організаційно-педагогічних умов. Структура комплексу умов має бути гнучкою, динамічною, розвиватись залежно від характеристик і складових процесу неперервного професійного зростання вчителя.

Аналіз досліджень і публікацій. Вивчення низки наукових праць свідчить про ємність понятійного базису дефініції умова, яка знаходиться на перетині дослідницьких полів філософії, психології та педагогіки. Професійний розвиток педагога обумовлений внутрішніми і зовнішніми умовами. Різні аспекти понять умова, педагогічні умови та організаційно-педагогічні умови розкриті в роботах В. Андрєєва, Ю. Бабанського, В. Белікова, Р. Гуревич, В. Загвязинського, М. Звєрєвої, І. Зязюна, А. Дьоміна, Н. Іпполітової, В. Клочко, М. Козяр, В. Монахова, А. Найна, I. Підласого, О. Пехоти, С. Рубінштейна, В. Сластьоніна, А. Хуторського, Л. Філіппова, Н. Яковлевої. Так, А. Дьомін, В. Лузан розглядають педагогічні умови підготовки фахівців у ЗВО; Р. Гуревич, В. Клочко, М. Козяр, В. Монахов - педагогічні умови застосування інформаційних технологій у процесі навчання у закладах вищої освіти. Ю. Бабанський визначає педагогічні 
умови як обставини або чинники, які визначають ефективність функціонування педагогічної системи. Л. Філіпова здійснила загальний аналіз змістовної складової та змісту поняття педагогічні умови. Слід зауважити, що, використовуючи вказаний термін, науковці і практики дотримуються доволі різних позицій щодо його трактування. Загалом педагогічні умови, що впливають на процес неперервного професійного зростання вчителів, потребують подальшого грунтовного дослідження.

Виклад основного матеріалу дослідження. У наукових вислідах поняття умова трактується доволі розмаїто. У Великому тлумачному словнику сучасної української мови даний термін пояснюється як: необхідна обставина для здійснення чого-небудь; особливості дійсності, за яких що-небудь відбувається. У філософії дефініція умова тлумачиться як категорія, що відображає зв'язок предмета і явищ тієї дійсності, у якій цей предмет перебуває, та без яких унеможливлюється існування означеної дійсності. Тобто умова - це компонент комплексу речей, їх станів та взаємодії, від наявності якого залежить існування явища. У педагогічній науці умовою називають середовище або певні обставини, у яких перебувають предмети чи явища, без яких їх існування унеможливлюється (Сагач, 2019).

Дослідники виділяють цільові, організаційні, змістовносмислові, динамічні, технологічні умови. До цільових належать: становлення інформаційного суспільства, оновлення його інформаційних потреб і тих форм, які їх задовольняють; до організаційних - зміни щодо організаційного контексту розвитку освітньої системи. Змістовно-складові умови полягають у формуванні ідейносмислового контексту освіти; динамічні - у накопиченні синергетичного потенціалу, що здатний протидіяти організаційній та ідейно-смисловій ентропії. До технологічних умов відносять зростання інноваційного та технологічного характеру перетво- рень системи освіти (Закраєвсь$\kappa a, 2014)$.

У педагогіці виділяють такі ознаки поняття умова, як: сукупність взаємопов'язаних та взаємообумовлених обставин процесу професійної діяльності; поєднання об'єктивних можливостей змісту, форм, методів спрямованих на вирішення завдань; єдність суб'єктивного й об'єктивного, внутрішнього і зовнішнього, сутності та явища; виявлення зв'язку предмета 3 явищами, без яких його існування унеможливлюється; виконання ролі правил щодо професійної діяльності. Виходячи зі сказаного, умова $\epsilon$ компонентом педагогічної системи (Андреев, 1996; Найн, 1999; Шнейдер, 2006). Найчастіше в дослідженнях 3 педагогіки науковці виділяють педагогічні умови і такий їх різновид, як організаційно-педагогічні умови, що є компонентами системи неперервного професійного розвитку педагогів.

Учені вказують на значну кількість педагогічних умов, які відрізняються залежно від мети та завдань конкретного дослідження, визначаючи їх як: чинники, які впливають на функціонування педагогічної системи, що залежна від них; обставини, якими обумовлюються напрями розвитку педагогічного процесу; поєднання змісту, методів, форм, прийомів і засобів педагогічної діяльності; поєднання об'єктивних можливостей змістовної складової навчання, методів та засобів його організації, які дозволяють успішно вирішувати педагогічні завдання (Закраєвська, 2014). Так, психологи трактують термін педагогічна умова як обставини, що прискорюють або, навпаки, пригальмовують формування та розвиток педагогічних явищ, процесів, систем, особистісних якостей. О. Братанич під педагогічними умовами розуміє поєднання змістовної складової, методів, форм організації та матеріальних можливостей щодо здійснення педагогічного процесу, що допомагає в успішному досягненні мети.

Н. Сенчина, вивчаючи педагогічні умови формування професійної рефлексії вчителів гуманітарних спеціальностей у після- дипломній освіті, педагогічними умовами називає комплекс тих засобів, які $\epsilon$ ефективними щодо формування професійної рефлексії педагога, та наявні в закладі післядипломної педагогічної освіти. Серед них дослідниця виділяє наступні: орієнтація системи післядипломної педагогічної освіти на формування у педагогів як фактора неперервного професійного та особистісного розвитку, педагогічної рефлексії та на актуалізацію їхньої рефлективності; організація рефлексивного професійного середовища; оновлення змістовної складової післядипломної педагогічної освіти, запровадження активних рефлексивних і діяльнісних технологій навчання; домінантна роль рефлексивних практик педагогів у закладах післядипломної педагогічної освіти (Сенчина, 2018).

Загалом одні дослідники схильні до думки про те, що педагогічні умови $є$ сукупністю засобів педагогічного впливу та можливостей педагогічного середовища, як матеріальних так i просторових, серед яких: зміст, методи та організаційні форми навчання і виховання; поєднання об'єктивних можливостей змісту, форм, методів та засобів середовища, як матеріальних так i просторових, що спрямовуються на досягнення поставлених завдань; об'єктивні можливості педагогічного процесу. Інші ж учні пов'язують педагогічні умови 3 конструюванням педагогічної системи, у якій ці умови виступають як один $з$ компонентів, a саме: компонент педагогічної системи, який відображає сукупність внутрішніх і зовнішніх елементів, які забезпечують іiі функціонування та подальший розвиток, тобто забезпечує розвиток особистісного аспекту суб'єктів освітнього процесу (внутрішні елементи) та чинить позитивний вплив на реалізацію процесуального аспекту системи (зовнішні елементи); змістовна характеристика одного 3 компонентів педагогічної системи, яким вважаємо засоби, організаційні форми та змістовну складову навчання, а також характер взаємодії між учителем і учнями. Певні категорії науковців дот- 
римуються думки про те, що педагогічні умови є планомірною роботою стосовно уточнення закономірностей освітнього процесу, яка забезпечує можливість перевірки результатів науковопедагогічного дослідження. При цьому вказують на необхідність послідовності умов, які перевіряються у межах гіпотези дослідження (Андреев, 1988; Зверева, 1987; Куприянов, 2001; Найн, 1995).

У контексті досліджуваної проблематики педагогічні умови можна визначити як елементи системи, на яких будується педагогічний процес та які забезпечують досягнення конкретної мети; організаційно-педагогічні умови - як комплекс взаємопов'язаних і взаємообумовлених компонентів, які забезпечують неперервність професійного зростання педагога (Сагач, 2019). Окремі ж дослідники розглядають їх як різновид педагогічних умов. Визначаючи організаційнопедагогічні умови, за яких відбувається професійне зростання вчителя у системі неперервної освіти, слід виходити з позиції того, що цей процес є цілісним, системно організованим, таким, який підпорядковується логіці неперервної педагогічної освіти. Озвучений підхід дозволяє виділити етапи названого процесу: етап професійного самовизначення та розвитку під час навчання у 3ВО; етап професійного вдосконалення та професійного зростання під час післядипломної підготовки в ході підвищення кваліфікації. Визначений поділ веде до розгляду змістовних складових процесу, адже будучи поєднаними його цілісністю, етапи відрізняються метою, змістом і методами.

Знаходячись на будь-якому етапі своєї професійної діяльності, учитель не може вважати себе повністю професійно сформованим. Знання, індивідуальний досвід, професійні та духовні цінності в поєднанні впливають на професійне зростання, яке обумовлюється мірою активності, спрямованої на вдосконалення. Етап післядипломної підготовки характеризується рівнем особистісного ставлення та становлення власної педагогічної позиції, орієнтацією на подолання труднощів і недоліків у професійній підготовці у процесі підвищення кваліфікації, яка спрямовується на розвиток тих сторін професійної діяльності педагога, що сприяють реалізації його особистісного та професійного потенціалу. На даному етапі відбувається інтеграція усіх складових професійного зростання вчителя, котрий має оволодіти здатністю переосмислювати власний педагогічний досвід, включати у якісно інноваційні технології вже засвоєні педагогічні дії (Сергеев, 1997; Сериков, 1994; Сери$\kappa о в, 1994)$. Підвищення кваліфікації покликане забезпечувати оновлення і перетворення професійних установок педагогів, поєднувати актуальні та стратегічні задачі. Сам зміст такого процесу спрямовується на розвиток індивідуального стилю педагогічної діяльності. У такому разі передбачається, крім набуття нових знань і розширення кругозору, сприйняття та засвоєння нових педагогічних ідей. Стосовно ж організаційно-педагогічних умов, що забезпечують неперервний професійний розвиток учителя, слід вказати на: створення спеціально організованого середовища; особистість викладача, котрий $є$ спікером під час проведення навчальних занять і консультантом; процесуальний компонент підвищення кваліфікації; змістовний компонент процесу неперервної освіти в закладах вищої та післядипломної педагогічної освіти.

Висновки та перспективи подальших досліджень. Професійне зростання педагога $\epsilon$ процесом якісних і кількісних перетворень його професійного потенціалу, що обумовлені як внутрішніми, так і зовнішніми умовами. Останні можна визначити елементами системи, на яких базується педагогічний процес та які забезпечують досягнення конкретної мети. В основі професійного розвитку педагога закладена детермінована активність особистості, адже він пов'язаний 3 перетвореннями складових професійного потенціалу, появою нових якостей на кожній сходинці.

Перспективи подальших дос- ліджень пов'язані 3 подальшим аналізом педагогічних та організаційно-педагогічних умов і чинників неперервного професійного розвитку педагога у процесі підвищення кваліфікації.

\section{СПИСОК ЛІТЕРАТУРИ}

Андреев, В. И. (1988). Диалектика воспитания и самовоспитания творческой личности. Казань : Издательство КГУ.

Андреев В. И. (1996). Педагогика творческого саморазвития. Инновационный курс. Казань : Издательство КГУ.

Закраєвська, О. Ю. (2014). Педагогічні умови підготовки майбутніх учителів початкової школи до формування в учнів умінь учитись. Наукові записки Вінницького державного педагогічного університету імені Михайла Коиююбинського, 42, 188-192.

Зверева, М. В. (1987). О понятии "дидактические условия". Новые исследования в педагогических науках. Педагогика, 1, 29-32.

Куприянов, Б. В. (2001). Современные подходы к определению сущности категории "педагогические условия". Вестник Костромского государственного университетата им. $H$. $A$. Некрасова, 2, 101-104.

Найн, А. Я. (1995). О методологическом аппарате диссертационных исследований. Педагогика, 5, 44-49.

Найн, А. Я. (1999). Рефлексивное управление образовательным учреждением: теоретические основы. Шадринск : Издательство ПО (Сеть).

Сагач, О. М. (2019). Організаційно-педагогічні умови неперервного професійного зростання майбутнього вчителя. Вісник Національного університету "Чернігівський колегіум" імені Т. Г. Шевченка, 4 (160), 202-206 DOI: $10.5281 /$ zenodo.3614670

Сенчина, Н. Г. (2018). Педагогічні умови формування педагогічної рефлексії вчителів гуманітарних спеціальностей у післядипломній освіті. Вісник Національного авіаційного універсиmemy, 1 (12), 100-106. DOI: 10.18372/2411-264X.12.12915

Сергеев, Н. К. (1997). Непре- 
рывное педагогическое образование: концепции и технодогии учебно-научно-педагогических комплексов. Спб.-Волгоград : Перемена.

Сериков, В. В. (1994). Личностно ориентированное образование. Педагогика, 5, 16-21.

Сериков, В. В. (1994). Личностный подход в образовании: концепции и технологии. Волгоград : Перемена.

Шнейдер, В. А. (2006). Развитие ценностных ориентаций преподавателей колледжа как фактор их профессионального роста. (Автореферат дис. ... канд. пед. наук. Магнитогорск.

\section{REFERENCES}

Andreev, V. I. (1988). Dialektika vospitaniya i samovospitaniya tvorcheskoi lichnosti. (Dialectics of education and self-education of a creative person). Kazan : Izdatelstvo KGU

Andreev, V. I. (1996). Pedagogika tvorcheskogo samorazvitiya. Innovacionnii kurs. (Pedagogy of creative selfdevelopment. Innovation course.). Kazan : Izdatelstvo KGU5

Zakraievska, O. Yu. (2014). Pedahohichni umovy pidhotovky maibutnikh uchyteliv pochatkovoi shkoly do formuvannia $\mathrm{v}$ uchniv umin uchytys. (Pedagogical conditions for the preparation of future primary school teachers for the formation of students' ability to learn.). Naukovi zapysky Vinnytskoho derzhavnoho pedahohichnoho universytetu imeni Mykhaila Kotsiubynskoho,
42, 188-192.

Zvereva, M. V. (1987). O ponyatii "didakticheskie usloviya". Novie issledovaniya v pedagogicheskih naukah. (On the concept of "didactic conditions". New research in the pedagogical sciences.). Pedagogika, 1, 29-32.

Kupriyanov, B. V. (2001). Sovremennie podhodi k opredeleniyu sush'nosti kategorii "pedagogicheskie usloviya". (Modern approaches to determining the essence of the category "pedagogical conditions"). Vestnik Kostromskogo gosudarstvennogo universitetata im. N. $A$. Nekrasova, 2, 101-104.

Nain, A. YA. (1995). O metodologicheskom apparate dissertacionnih issledovanii. (On the methodological apparatus of dissertation Pedagogika, 5, 44-49.

Nain, A. YA. (1999). Refleksivnoe upravlenie obrazovatelnim uchrezhdeniem: teoreticheskie osnovi: Monografiya. (Reflexive Management of an Educational Institution: Theoretical Foundations: Monograph). Shadrinsk : Izdatelstvo PO (Set). Sahach, O. M. (2019). Orhanizatsiino-pedahohichni umovy neperervnoho profesiinoho zrostannia maibutnoho vchytelia. (Organizational and pedagogical conditions of continuous professional growth of the future teacher). Visnyk Natsionalnoho universytetu "Chernihivskyi kolehium" imeni T. H. Shevchenka, 4 (160), 202-206.
Senchyna, N. H. (2018). Pedahohichni umovy formuvannia pedahohichnoi refleksii vchyteliv humanitarnykh spetsialnostei $\mathrm{u}$ pisliadyplomnii osviti. (Pedagogical conditions of formation of pedagogical reflection of teachers of humanitarian specialties in postgraduate education). Visnyk Natsionalnoho aviatsinoho universytetu, 1 (12), 100-106.

Sergeev, N. K. (1997). Neprerivnoe pedagogicheskoe obrazovanie: koncepcii i tehnodogii uchebno-nauchnopedagogicheskih kompleksov. (Voprosi teorii). (Continuing teacher education: concepts and technologies of educationalscientific-pedagogical complexes. Spb.-Volgograd : Peremena.

Serikov, V. V. (1994). Lichnostno orientirovannoe obrazovanie. (Personally oriented education). Pedagogika, 5, 16-21.

Serikov, V. V. (1994). Lichnostnii podhod v obrazovanii: koncepcii i tehnologii: Monografiya. (Personal approach in education: concepts and technologies). Volgograd : Peremena.

Shneider, V. A. (2006). Razvitie cennostnih orientacii prepodavatelei kolledzha kak faktor ih professionalnogo rosta. (The development of value orientations of college teachers as a factor in their professional growth.). (Avtoreferat dis. ... kand. ped. nauk). Magnitogorsk.

Стаття надійшла 14.03.2020p. 